\title{
АНАЛІЗ МОЖЛИВОСТЕЙ ВИКОРИСТАННЯ ВИСТАВКОВОЇ ДІЯЛЬНОСТІ ВИРОБНИЧИМИ ПІДПРИЄМСТВАМИ УКРАЇНИ ДЛЯ ПРОСУВАННЯ ПРОДУКЦІї НА МІЖНАРОДНИХ РИНКАХ
}

\section{ANALYSIS OF POSSIBILITY TO USE AN EXHIBITION ACTIVITY BY PRODUCTION ENTERPRISES OF UKRAINE FOR PROMOTION OF PRODUCTS IN THE INTERNATIONAL MARKET}

\author{
Кравченко Оксана Михайлівна \\ кандидат економічних наук, \\ Державний університет «Одеська політехніка» \\ ORCID: https://orcid.org/0000-0002-3389-3218 \\ Букорос Євгенія Олександрівна \\ студентка, \\ Державний університет «Одеська політехніка» \\ ORCID: https://orcid.org/0000-0002-6275-3513 \\ Kravchenko Oksana, Bukoros Evgenia
Odessa Polytechnic State University
}

\begin{abstract}
Стаття присвячена аналізу можливостей використання виставкової діяльності як інструменту просування продукції виробничих підприємств на міжнародному ринку. Проаналізовано доцільність участі у виставках для підприємств різного масштабу. Визначено основні тенденції розвитку виставкової індустрії у світі та Україні, її роль при виході з кризи, пов'язаною з пандемією. Надані рекомендації та пропозиції щодо вибору міжнародних виставок. Особлива увага надана аналізу існуючих міжнародних заходів, в результаті якого їх систематизовано за різними напрямками. Також у статті висвітлено основні завдання та цілі участі підприємств у виставках. Обґрунтовано, що виставкова діяльність для виробничих підприємств сприяє просуванню продукцію на нових ринках, встановленню нових контактів з діловими партнерами, слідкуванню за розвитком своїх потенційних конкурентів та загальних тенденцій у своїй галузі.
\end{abstract}

Ключові слова: виставкова діяльність, просування продукції, виставка, вибір виставки, міжнародні ринки.

Статья посвящена анализу возможностей использования выставочной деятельности как инструмента продвижения продукции производственных предприятий на международном рынке. Проанализирована целесообразность участия в выставках для предприятий разного масштаба. Определены основные тенденции развития выставочной индустрии в мире и Украине, ее роль при выходе из кризиса, связанного с пандемией. Даны рекомендации и предложения по выбору международных выставок. Особое внимание уделено анализу существующих международных мероприятий, в результате которого они были систематизированы по разным направлениям. В статье освещены основные задачи и цели участия предприятий в выставках. Обосновано, что выставочная деятельность способствует продвижению продукции на новых рынках, установлению контактов с деловыми партнерами, наблюдению за развитием своих потенциальных конкурентов и общих тенденций.

ключевые слова: выставочная деятельность, продвижение продукции, выставка, выбор выставки, международные рынки.

In modern conditions, when the foreign trade balance of Ukraine has been negative for more than ten years, the issue of promoting the products of domestic enterprises to international markets is especially relevant. Export potential building should become a priority for the development of manufacturing enterprises, providing an opportunity to diversify markets and optimize profits for enterprise, and also to promote positive changes in the country's trade balance. The purpose of the article is to analyze the possibilities of using exhibition activities by Ukrainian manufacturing enterprises for promotion products to international markets, to form sources of information about exhibition 
events, to give examples of exhibition events in different countries, to demonstrate the necessity of participation in exhibition events for domestic enterprises. The article is devoted to the analysis of the possibilities of using exhibition activity as a tool for promoting the products of industrial enterprises on the international market. Was analyzed the expediency of participation in exhibitions for enterprises of different scales. The main trends in the development of the exhibition industry in the world and in Ukraine, its role in overcoming the crisis associated with the pandemic. Recommendations and suggestions on the choice of international exhibitions are given. Particular attention is paid to the analysis of existing international measures, as a result of which they are systematized in different areas. The article also highlights the main objectives and goals of enterprise participation in exhibitions. It is substantiated that exhibition activity for manufacturing enterprises promotes products in new markets, establishing new contacts with business partners, monitoring the development of their potential competitors and general trends in their industry. Was recommend to use all available tools to promote products on foreign markets through exhibition activities, using exhibition platforms in two directions: to present their own products, and to analyze the products of competitors.

Keywords: exhibition activity, product promotion, exhibition, exhibition selection, international markets.

Постановка проблеми. В сучасних умовах, коли сальдо зовнішньоторговельного балансу України вже понад десять років $€$ хронічно від'ємним, питання просування продукції вітчизняних підприємств на міжнародні ринки стоїть особливо гостро. Робота над нарощуванням експортного потенціалу має стати пріоритетним напрямом розвитку виробничих підприємств, забезпечивши можливість не тільки диверсифрікувати ринки збуту та оптимізувати прибуток, але й сприяти позитивним змінам в торгівельному балансі країни. Чим більші обсяги експорту, тим більші обсяги валюти поступають в країну, що сприяє зростанню багатства країни та добробуту громадян. Активна участь у міжнародних виставках надає можливість не тільки представити власну продукцію та знайти потенційних споживачів, партнерів, або інвесторів, проте також, проаналізувати конкурентів, дізнатись більше про споживчі вподобання на цільових ринках, ознайомитись 3 останніми тенденціями техніки і технології виробництва та реалізації аналогічної продукції.

Аналіз останніх досліджень та публікацій. Питанням використання виставкової діяльності виробничими підприємствами України для просування продукції на міжнародних ринках присвячено труди багатьох дослідників: Божкова В.В. Чикалова А.С., Продіус Ю.І., Сутягіна А.В., Вдовічена О.Г., Нергеш А.В., П'ятницька Г.Т., Головчук Ю.О. $[1-3 ; 5 ; 6]$.

Мета статті полягає в тому, щоб проаналізувати можливості використання виставкової діяльності виробничими підприємствами України для просування продукції на міжнародних ринках, сорормувати джерела інформації щодо пошуку виставкових заходів, навести приклади виставкових заходів в різних країнах, продемонструвати необхідність участі в виставкових заходах для вітчизняних виробничих підприємств.
У розвитку сучасної економіки виставкова діяльність $€$ одним із найважливіших інструментів просування продукції на міжнародних ринках. Виставка - це спеціально організований бізнес-захід, який пов'язаний із демонстрацією продукції з метою ії просування як на внутрішньому, так і на зовнішньому ринках [1]. Продіус Ю.І. [2, с. 160] зазначає, що виставка $є$ коморортним засобом, що сприяє поширенню та отриманню широкого кола комерційних, економічних та технічних повідомлень при відносно доступній вартості самого заходу. Однією із найсуттєвіших переваг виставки для споживача $€$ можливість особисто ознайомитись із продукцією, перевірити її фрункціонування, оцінити якість та отримати усю необхідну інформацію у виробника. Промислова виставка необхідна всім виробничим підприємствам незалежно від галузі, типу продукції або масштабу виробництва, оскільки компанія отримує ряд можливостей для ефрективного просування свого товару.

Однією з основних переваг виставок $€$ зосередження зразків величезної кількості товарів, вироблених у різних країнах [3, с. 854]. Експоненти та відвідувачі можуть ознайомитись із існуючими пропозиціями на глобальному ринку, вивчити асортимент та ефективність застосування наявних зразків, оцінити конкурентні переваги власного та конкуруючого виробництва, порівняти ціни і якісні характеристики представленого товару, знайти нові ділові контакти та укласти договори. Зазначені вище фрактори забезпечують постійний ріст популярності виставок, що в результаті з кожним роком залучає більшу кількість експонентів та відвідувачів.

Отже, виставкова діяльність - це найцінніший інструмент, за допомогою якого компанія здатна просувати продукцію на нові ринки, укладати нові контакти 3 діловими партнерами, слідкувати за розвитком своїх потенційних конкурентів та бути в курсі загальних тенденцій у своїй галузі $[1$, с. 161]. 
У світовому масштабі виставкову діяльність регулює Всесвітня асоціація виставкової індустрії (UFI), яка щорічно підбиває підсумки стосовно масштабу діяльності усіх учасників індустрії по всьому світу та складає статистику. За останніми даними асоціації [4], що були опубліковані 6 травня 2021 року, не зважаючи на пандемію, та пов'язаний з цим спад економічної активності у всіх сорерах господарювання, за 2020 р. в світі будо проведено близько 33 тис. виставкових заходів. Це стало можливим завдяки тому, що деякі виставкові заходи було переведено в онлайн фрормат. Виставкова діяльність генерує близько 493 млрд. Євро (551 дол. США) В2В продажів щороку, стимулюючи галузі, що прагнуть відновитись і знову підключитися до представлення своєї продукції у виставковому залі. Виставкова діяльність має неймовірний вплив на глобальну економіку. Було зазначено, що 80\% замовників виставок - це малі та середні підприємства, які найбільше постраждали від пандемії. Майже 4,25 мільйона малих підприємств долучаються до персоналізованих торгових платорорм на регулярній основі, з метою зустріти кваліфікованих покупців своєї продукції.

щорічно компанії-експоненти мають можливість представити свою продукцію, активно просуваючи її на зовнішні ринки, в результаті чого укладаються нові договори, розширюються ділові контакти, закріплюються імідж компанії тощо. Тому можна зробити висновки, що виставочна індустрія $€$ важливою як механізм розвитку глобальної та національної економіки.

Г.Т. Пятницька [5] зазначає, що у Європі серед провідних країн на ринку виставкових послуг варто виділити: Нідерланди, Туреччину, Італію, Німеччину, Францію та Іспанію. Ці країни вже давно зрозуміли перспективність розвитку виставкової діяльності, як спосіб поповнення бюджету та створення додаткових робочих місць, а також як спосіб підтримки ділового іміджу як самої країни, так і їхніх підприємств. Проте Україна поки що не належить до лідерів виставкової індустрії в світовому та європейському масштабі.

Сьогодні в Україні важливість виставкової індустрії постійно продовжує зростати. Оскільки виставка не тільки демонструє стан економіки нашої країни та окремих галузей, а й використовується як ефективний інструмент для просування продукції на міжнародний ринок вітчизняних виробників. Не дивлячись на складне соціально-політичне становище, Україна залишається привабливою для світового бізнесу завдяки наявності виробничих потужностей у більшості секторів виробництва, багатої сировинної бази, вигідному географрічному положенню, а також кваліфрікованому людському ресурсу з близьким до європейців менталітетом.

Крім того, слід зазначити, що Україна активно рухається у бік розвитку іміджу країни-виробника продукції для міжнародних ринків. Якщо раніше у світовому масштабі наша країна була відома переважно як сировинна база, то тепер значно збільшується кількість виробничих підприємств та стартапів практично у всіх сорерах бізнесу. Завдяки цьому Україна стає дуже привабливою для різних інвестиційних проектів.

Головчук Ю.О. [6, с. 92] також зазначає, що виставка $€$ сполучною ланкою між внутрішнім та зовнішнім ринками і сприяє залученню іноземних інвестицій для розвитку українських організацій, а також налагодженню нових партнерських відносин. Оскільки міжнародні виставки є майданчиком для ділових зустрічей головних учасників обраного ринку, демонстрації та презентації своєї продукції, то підприємствам будь-якого розміру корисно приймати участь у виставках не тільки задля збільшення потенційних споживачів, а й для пошуку інвесторів. Проте, незважаючи на ряд переваг, які надають виставки, вітчизняні підприємства досі недооцінюють зазначений захід як інструмент для просування своєї продукції.

Слід зауважити, що виставкова діяльність, в першу чергу, найбільш необхідна малим та середнім підприємствам. Подібний захід один 3 найесрективніших способів швидко та змістовно заявити про своє існування на міжнародному ринку. Компанії навіть при незначному маркетинговому бюджеті, що $€$ характерним для невеликих компаній, може приймати участь у міжнародній виставці. Оскільки на сьогоднішній день існує величезний вибір виставок за спеціалізацією, масштабом та країною проведення, в залежності від чого залежить вартість та ефрективність участі.

Починаючи з 2019 року пандемія внесла свої корективи у світову економіку, що безпосередньо вплинуло і на виставкову діяльність. За даними Всесвітньої асоціації виставкової індустрії UFI, у 2020 році у зв'язку з пандемією було втрачено близько $72 \%$ доходів. Проте вже у 2021 році UFI прогнозують позитивну динаміку зростання виставкової індустрії в двічі, відносно 2020 р. [7].

На сьогоднішній день виставкова діяльність набуває нового особливого значення для 
всіх підприємств: саме «живі» бізнес заходи можуть допомогти суттєво прискорити відновлення світової економіки після карантину. Участь у виставках, окрім зазначених вище основних завдань, дає компаніям низку інших важливих переваг, а саме: відновити продажі, відновити та налагодити втрачені зв'язки, повернути робочі місця і в майбутньому пришвидшити прибуток від своєї діяльності. До того ж, варто відмітити, що виставкова галузь сприяє підтримці і відновленню суміжних індустрій, як наприклад: міжнародні перевезення та логістичні послуги, туризм та готельний бізнес, касре та ресторани, середні та малі підприємства сорери послуг. Усі компанії прагнуть якнайшвидше повернутись у звичний режим. Проте деякі ринки зможуть швидко вийти 3 кризи, а іншим знадобиться значно більше часу. У будь-якому разі виставочні зали прискорять цей процес. Отже, сьогодні виставкова діяльність - це не тільки інструмент просування продукції на міжнародному ринку, а й спосіб виходу з кризи пов'язаної з пандемією.

Участь у міжнародних виставках - це унікальна нагода повідомити зарубіжним ринкам про своє існування та запропонувати більш вигідні умови для співпраці $[1$, с. 15]. Задля ефрективної участі у виставках підприємство має здійснити якісну підготовку. При прийнятті рішення про участь у виставці компанії необхідно чітко визначити цілі, які поділяються за наступними категоріями:
- маркетингові, що включають вивчення конкурентів, тенденції ринку, аналіз асортименту та просування власної продукції;

- комерційні, що полягають у пошуку нових клієнтів та укладанні нових угод;

- іміджеві, які передбачають підтримку або орормування іміджу компанії.

Зазвичай керівництво підприємства покладає процес організації виставкової діяльності на відповідного менеджера або на запрошеного зовнішнього консультанта. За ідеальним сценарієм підготовку до виставки слід починати за 1 рік (або навіть більше) до відкриття виставки [6, с. 95]. Одним 3 найважливіших завдань спеціаліста $є$ вибір виставки, що здійснюється у декілька етапів, що були систематизовані нами на засадах вивченого матеріалу (рис. 1). При цьому відповідальний менеджер має стежити за різними джерелами інфрормації (професійні журнали, інтернетпортали, наукові дослідження, конкуренти, постачальники тощо) та моніторити існуючи виставки.

Вдовічена О.Г. [3, с. 855] зазначає, що періодичність участі у виставках залежить від віку та успішності компанії, яка просувається. Для маловідомих компаній, що тільки виходять на новий ринок, слід приймати участь в якомога більшій кількості заходів. Тоді як для компаній, що мають міцну репутацію на своєму ринку, достатньо відвідувати однієї-двох найбільших міжнародних виставок для підтримки свого

1 етап. Визначити нові ринки як напрямок для майбутньої діяльності.

Проаналізувати можливості щодо представлення продукції,

дослідити потреби та запити споживачів кожного ринку

2 етап. Проаналізувати наявні виставки ( за галуззю, статусом, масштабом, країною проведення, цільовою аудиторією, вартістю участі)

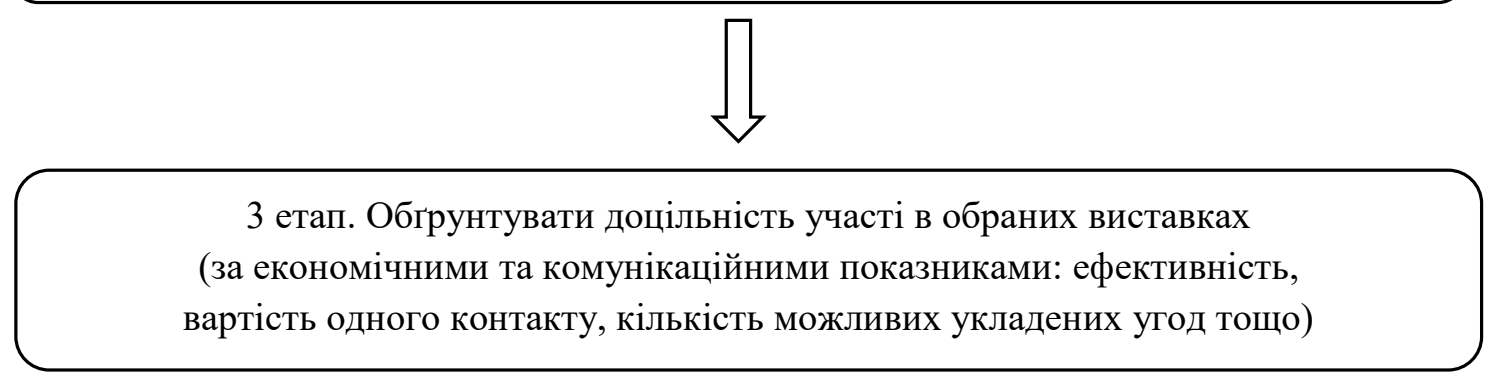

Рис. 1. Етапи вибору виставки

Джерело: систематизовано автором на основі [1] 
іміджу. В будь-якому разу бути активним у виставковій діяльності $€$ необхідністю для підприємств різного масштабу. Крім того, враховуючи сучасну кількість конкуруючих компаній відсутність просування на найбільших галузевих виставках може негативно вплинути як на репутацію, так и на майбутній прибуток.

Міністерство економіки України [8] розглядає виставкову діяльність як спосіб підтримки експорту. Також слід зазначити, що Мінекономіки усіляко підтримує та заохочую підприємства до участі на міжнародних виставках. Оскільки зазначені заходи сприяють збільшенню обсягів експорту конкурентоспроможної продукції, залученню зовнішніх інвестицій, зміцненню міжнародних зв'язків, підвищення міжнародного іміджу держави тощо. Для зручності пошуку та вибору міжнародних виставок Мінекономіки на своєму офріційному порталі створив рекомендації із списками виставок за країнами. Ми проаналізували виставки, що пропонує Міністерство та обрали найперспективніші, на наш погляд, за наступними напрямками: Туреччина, Данія, Іспанія, Франція та Греція (рис. 2).

Крім того, Міністерство розвитку економіки рекомендує також ряд міжнародних виставок, що проходять на території України (рис. 3).
Тому ті підприємства, що тільки починають активно вести свою виставкову діяльність, можуть для початку спробувати прийняти участь у зазначених виставках і отримати необхідний досвід.

Проаналізувавши рекомендації Мінекономіки було виявлено ряд відсутніх країн, які $€$ достатньо розвинутими у світовому масштабі за виставковою діяльністю, тому ми пропонуємо виробничим підприємствам також розглянути міжнародні виставки в таких країнах, як Нідерланди, Німеччина, Польща, Болгарія та Китай (рис. 4).

Отже, сьогодні існує широкий вибір міжнародних виставок у всьому світі. Кожне виробниче підприємство може обрати для себе захід в залежності від потрібного регіону, галузі, масштабу та вартості участі. Слід наголосити, що при виборі виставки важливо враховувати відповідність продукції вимогам конкурентного ринку та складність «вхідних бар'єрів» на ньому.

Просування продукції на міжнародному ринку є невід'ємною частиною стратегічного розвитку компанії і складається з цілої системи дій, які спрямовані на посилення впізнаванності бренду на початкових етапах, посилення позицій на ринку в подальшому

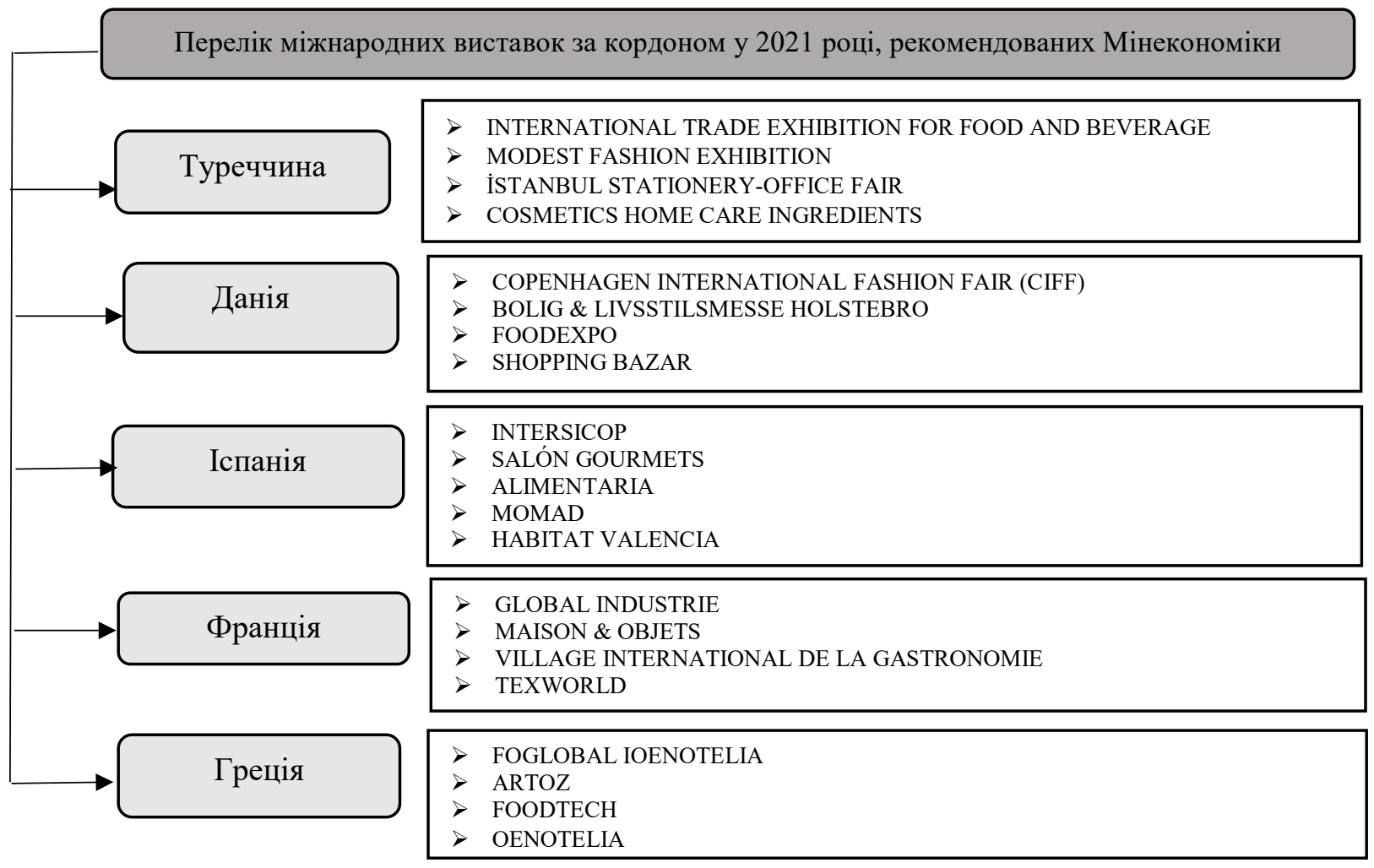

Рис. 2. Перелік деяких виставок за кордоном у 2021 році, рекомендованих Мінекономіки України

Джерело: розроблено автором на основі [8] 


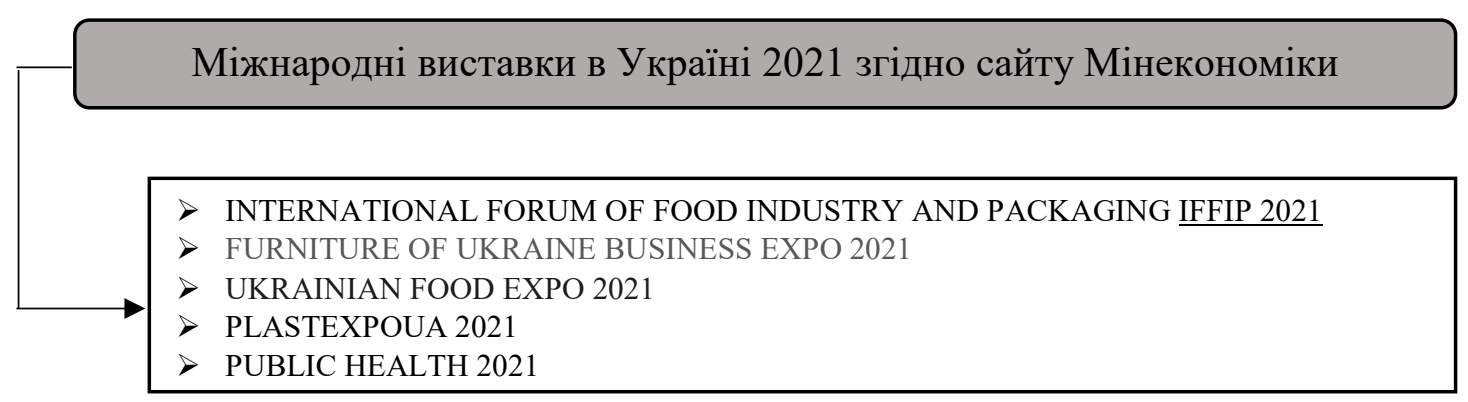

Рис. 3. Міжнародні виставки, що проводяться на території України у 2021 році, зазначені на сайті Мінекономіки України

Джерело: розроблено автором на основі [8]

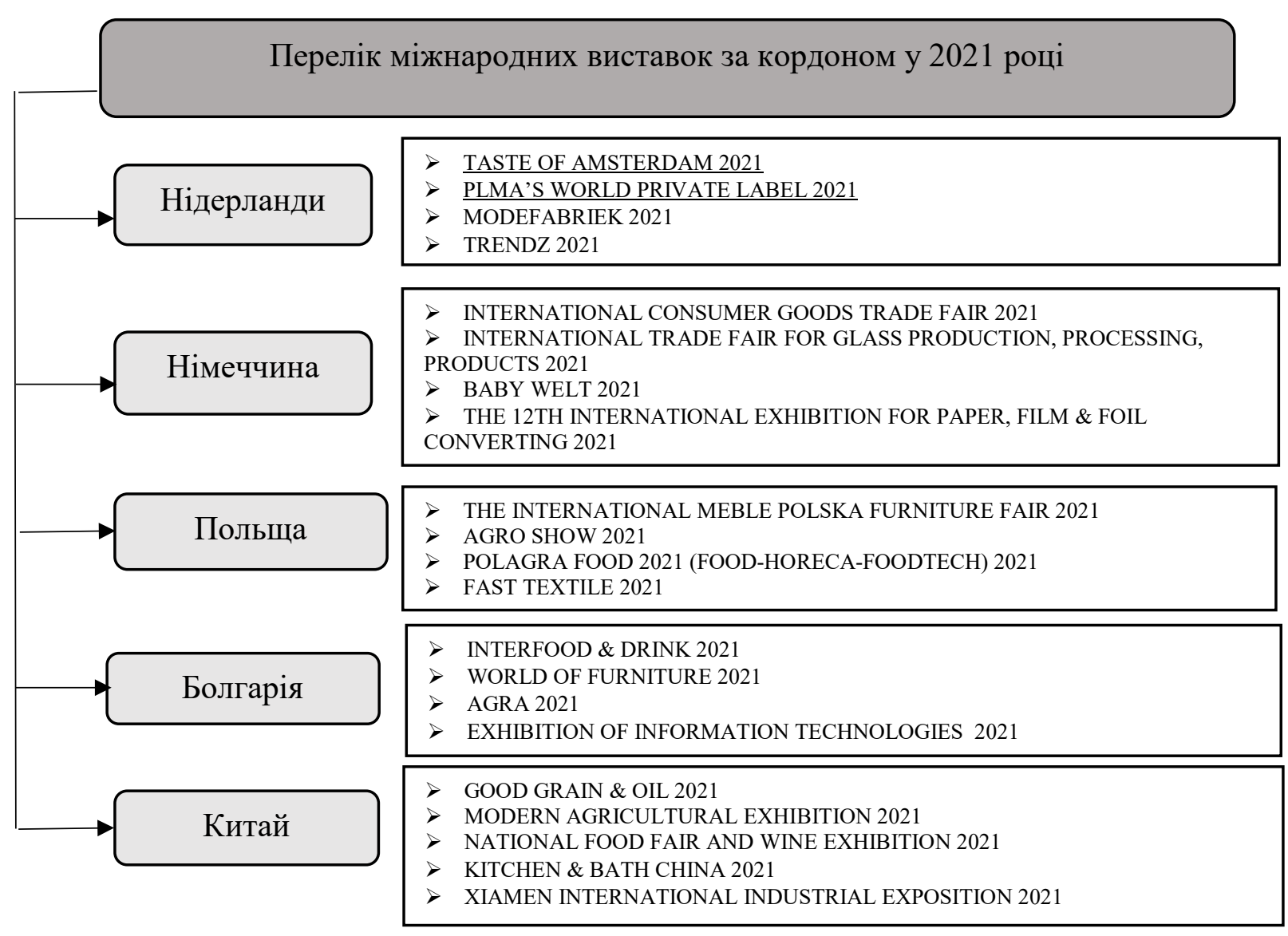

Рис. 4. Приклад наявних міжнародних виставок за кордоном у 2021 році, що не представлені на сайті Мінекономіки

Джерело: згруповано автором на основі [9]

та підтримки іміджу на весь період існування компанії. Все це в повній мірі забезпечує виставкова діяльність. Кожна виставка приносить певні результати своїм учасникам, саме тому більшість провідних компаній беруть участь в них постійно.

Висновки. Під час пандемії, досить багато компаній наголошували, що відсутність виставкових заходів негативно позначається на їх здатності створювати новий, та підтри- мувати існуючий бізнес. Скорочення виставкових заходів по всьому світу, та водночас скорочення кількості відвідувачів призвело до того, що було залучено менше потенційних клієнтів, багато компаній відзначають негативний вплив на свої продажі через неможливість приймати участь у виставках. Це доводить важливість виставкової діяльності для виробничих підприємств. Ми поділяємо думку багатьох світових експертів, що заходи 
3 можливістю безпосередньої комунікації - це найшвидший шлях до відновлення економіки країн; саме вони мають забезпечити компаніям найкращу віддачу від інвестицій і повноцінний доступ до ринків. Ми рекомендуємо українським виробничім підприємствам використовувати усі наявні інструменти просування продукції на зовнішні ринки через виставкову діяльність, використовуючи виставкові платформи в двох напрямах: для представлення світу продукції власного виробництва, та водночас, для аналізу продукції конкурентів. Для пошуку виставкових заходів можна використовувати як інформацію надану Мінекономіки України, що відрізняється доступністю, адже вона вже адаптовано до україномовного читача, а також, рекомендуємо використовувати міжнародні інфрормаційні платорорми для пошуку найбільш корисних виставок для кожного окремого виду продукції.

\section{СПИСОК ВИКОРИСТАНИХ ДЖЕРЕЛ:}

1. Божкова В.В., Чикалова А.С. Виставкова діяльність як ефективний інструмент просування промислової продукції на нові ринки збуту. Маркетинг і менеджмент інновацій. 2015. № 3. С. 11-14.

2. Продіус Ю.І., Сутягіна А.В. Проблеми виставкової діяльності в умовах нестабільності зовнішнього середовища. Економіка: реалії часу. 2016. № 4. С. 160-167.

3. Вдовічена О.Г., Нергеш А.В. Перспективи участі бренду підприємств у виставкових заходах: світовий та вітчизняний досвід. Молодий вчений. 2018. № 1. С. 854-858.

4. Exhibitions generate $€ 493$ ( $\$ 551$ ) billion in business sales each year, driving industries eager to recover and reconnect back to the show floor (May 2021): data from the official web-site of the Global Association of the Exhibition Industry. URL: https://www.ufi.org/wp-content/uploads/2021/05/MR_GED_Exhibitions-generate-E493-551-billionin-business-sales-each-year_6may2021.pdf

5. П'ятницька Г.Т. Перспективи розвитку виставкової діяльності в Україні: кластерний підхід. Есрективна економіка. 2016. № 9. URL: http://www.economy.nayka.com.ua/?op=1\&z=5139

6. Головчук Ю.О. Виставково-ярмаркові заходи як складові фоомування партнерських відносин. Агросвіт. 2020. № 4. С. 91-98.

7. UFI Global Barometer provides 2020 results and 2021 perspectives for the exhibition industry): data from the official web-site of the Global Association of the Exhibition Industry. URL: https://www.ufi.org/mediarelease/ufiglobal-barometer-provides-2020-results-and-2021-perspectives-for-the-exhibition-industry/

8. Перелік виставок і ярмарків за кордоном у 2021 році : Офіційний сайт Міністерства економіки України. URL: https://www.me.gov.ua/Documents/Detail?lang=uk-UA\&id=d85c6c61-f1db-4239-bb79-cacea5ae085a\&title=P erelikVistavokIYarmarkivZaKordonomU2021-Rotsi

9. Trade Shows and Exhibitions by Country: Trade Fair Dates. URL: https://www.tradefairdates.com/tradeshows-by-countries.php

\section{REFERENCES:}

1. Bozhkova V.V., Chikalova A.S. (2015) Vystavkova diialnist yak efektyvnyi instrument prosuvannia promyslovoi produktsii na novi rynky zbutu [Exhibition activity as an effective tool for promoting industrial products in new markets]. Marketing and innovation management, no. 3, pp. 11-14.

2. Prodius Y.I., Sutyagina A.V. (2016) Problemy vystavkovoi diialnosti v umovakh nestabilnosti zovnishnoho seredovyshcha [Problems of exhibition activity in conditions of instability of the external environment]. Economics: the realities of time, no. 4, pp. 160-167.

3. Vdovi chena O.G., Nergesh A.V. (2018) Perspektyvy uchasti brendu pidpryiemstv u vystavkovykh zakhodakh: svitovyi ta vitchyznianyi dosvid [Prospects for the participation of the brand of enterprises in exhibition events: world and domestic experience]. Young Scientist, no. 1, pp. 854-858.

4. Exhibitions generate $€ 493$ ( $\$ 551$ ) billion in business sales each year, driving industries eager to recover and reconnect back to the show floor (May 2021): data from the official web-site of the Global Association of the Exhibition Industry. URL: https://www.ufi.org/wp-content/uploads/2021/05/MR_GED_Exhibitions-generate-E493-551-billion-in-business-sales-each-year_6may2021.pdf

5. Pyatnytska G.T. (2016) Perspektyvy rozvytku vystavkovoi diialnosti v Ukraini: klasternyi pidkhid [Prospects for the development of exhibition activity in Ukraine: a cluster approach]. Effective Economy, no. 9. URL: http://www.economy.nayka.com.ua/?op=1\&z=5139

6. Golovchuk Yu.O. (2020) Vystavkovo-yarmarkovi zakhody yak skladovi formuvannia partnerskykh vidnosyn [Exhibition and fair events as part of the formation of partnerships]. Agrosvit, no. 4, pp. 91-98. 
7. UFI Global Barometer provides 2020 results and 2021 perspectives for the exhibition industry): data from the official web-site of the Global Association of the Exhibition Industry. URL: https://www.ufi.org/mediarelease/ufi-global-barometer-provides-2020-results-and-2021-perspectives-for-the-exhibition-industry/

8. Perelik vystavok i yarmarkiv za kordonom u 2021 rotsi: Ofitsiinyi sait Ministerstva ekonomiky Ukrainy [List of exhibitions and fairs abroad in 2021: Official site of the Ministry of Economy of Ukraine]. URL: https://www.me.gov.ua/Documents/Detail?lang=uk-UA\&id=d85c6c61-f1db-4239-bb79-cacea5ae085a\&title= PerelikVistavokIYarmarkivZaKordonomU2021-Rotsi

9. Trade Shows and Exhibitions by Country: Trade Fair Dates. URL: https://www.tradefairdates.com/tradeshows-by-countries.php 